Jurnal Administrasi Publik (Public Administration Journal), 10(1) June 2020

ISSN 2088-527X (Print) ISSN 2548-7787 (Online), DOI: https://doi.org/10.31289/jap.v10i1.2973

Jurnal Administrasi Publik

(Public Administration Journal)

Available online http://ojs.uma.ac.id/index.php/jap

\title{
Implementation of Decency Test and Strategic Position Feasibility in Accordance with Law Number 5 of 2014 in Medan City Government, Deli Serdang Regency and Samosir Regency
}

\author{
Robinson Sembiring * Muba Simanihuruk** \\ Faculty of Social and Political Sciences, Universitas Sumatera Utara, Indonesia \\ Received: October 11, 2019; Accepted: April 11,2020; Published: May 8, 2020 \\ *Coresponding Email: * rsembiring@mvself.com \& ** mubasima@gmail.com
}

\section{Abstracts}

This study seeks (1) to explore local government strategies in selecting personnel for strategic positions; (2) studying the role of the RPA (Regional Personnel Agency) in carrying out the Decency and Appropriateness Test of personnel applying for the "Position Auction"; (3) studying the role of the Sekwilda in conducting the fit and proper test; (4) searching for the fit and proper test models according to local characteristics. The agenda for improving Indonesia's public sector becomes a necessity if it is linked to developments and current demands, such as good governance, professionalism, transparency, accountability, ethical and moral enforcement in the delivery of public services (Milakovich and Gordon, 2007 in Nurprojo, 2014). The improvement of the Indonesian bureaucracy through the enactment of the State Civil Apparatus Law is expected to be able to realize a better Indonesian bureaucracy through the performance of professional civil servants based on competence and competition by establishing a merit system in State Civil Apparatus management. This study uses a qualitative paradigm by relying on researchers as data collectors through indepth interviews and participatory observation. In-depth interviews were conducted with local elites (Head of the Regional Personnel Agency, Staff of the Regional Personnel Agency, Members of the Regional People's Representative Council, Members of the Selection Committee, Non-Governmental Organizations, the media and intellectuals) who were concerned with local governance. This is done to determine the implementation of the propriety test and due diligence in the context of filling strategic positions in the regions.

Keywords : Regional Autonomy, Dynasty Politics, Identity Politics, Strategic Position Recruitment.

How to Cite: Sembiring, R \& Simanihuruk, M (2020). Implementation of Decency Test and Strategic Position Feasibility in accordance with Law No. 5 of 2014 in Medan City Government, Deli Serdang Regency and Samosir Regency. Jurnal Administrasi Publik (Public Administration Journal). 10(1): 1-11 


\section{INTRODUCTION}

Based on the 2015 Corruption Perception Index Report released by Transparency International, Open Government 2015, IMD World Talent 2015, Worldwide Governance Indicators 2012 Indonesia's position in the field of Governmet Effectiveness Indonesia ranks far below Singapore. The reports above report several indicators used in the Bureaucracy Reform program, and from that report we can see that the bureaucracy in Indonesia is still far from good words compared to neighboring countries such as Singapore, Malaysia and even Thailand. Based on these reports, the agenda for improving the Indonesian public sector becomes a necessity if it is linked to current developments and demands, such as globalization or trade liberalization, good governance, professionalism, transparency, accountability, ethical and moral enforcement in the delivery of public services (Milakovich and Gordon, 2007 in Nurprojo, 2014).

The beginning of improving the performance of Indonesia's bureaucracy began in the 1998 Reforms. Indonesia, which initially had a Weberian model of bureaucratic system that was swollen and slow-moving and indicated centralistic patronage, experienced improvements towards a better direction. Improvement of bureaucracy continues with the passing of Law no. 43 of 1999 concerning Amendments to Law No. 8 of 1974 concerning Principal Personnel. The presence of the Act rearranges Indonesia's bureaucracy by eliminating the impression of patronage through the formulation of duties and functions, and job grading indicators. However, implementing Law No. 43 of 1999 turned out to be not so positive value for the performance of the Indonesian bureaucracy.

Efforts to improve Indonesia's bureaucracy continue again with the ratification of Law no. 5 of 2014 concerning State Civil Apparatus which became effective on January 15, 2014. Through the Law on State Civil Apparatus it is hoped that a better Indonesian bureaucracy can be achieved through the performance of professional civil servants based on competence and competition by establishing a merit system in the management of the State Civil Apparatus (Dwiyanto, 2014; Nugroho, 2014).

Actually the Merit System already existed when Law No. 43 of 1999 concerning Amendments to Law No. 8 of 1974 in Article 17 (2) states that "the appointment of a Civil Servant in a position is carried out based on the principle of professionalism in accordance with the competencies, work performance, and rank levels set for that position as well as other objective conditions without differentiating sex, ethnicity, religion, race, or class. " However, in its implementation, the policy was not well transformed at the level of management in an integrated manner so that filling the position was carried out instead based on merit. Terms of filling positions are not applied proportionally. As a result of the implementation of the Civil Service Act that has not emphasized competence and performance in the management of the State Civil Apparatus, in practice we find that seniority and political / favotritism / patronage closeness are precisely the decisive conditions in each filling position (closed career system) (Prasodjo) , 2014).

Therefore the need for a merit system is further strengthened by the issuance of the State Civil Apparatus Act. In the State Civil Apparatus Act it states:

"Management of the State Civil Apparatus is organized based on the Merit System". Described in Article 1 (22) "Merit System is the policy and Management of the State Civil Apparatus based on qualifications, competencies, and performance fairly and fairly with no distinction of political background, race, color, religion, origin, gender, marital 
status, age or disability conditions. " In the implementation of the Law on State Civil Apparatus strengthening the application of the merit system in a number of ways, including: the application of a merit-based recruitment system, an open career system in every filling of positions especially the Transportation Management Service, forming the State Civil Apparatus Commission as the guardian of the merit system, presenting the District Election Committee, firm and performance-based reward and punishment, and protection from political intervention (Prasodjo, 2014)

But the presence of the State Civil Apparatus Law is not not reaping the pros and cons even from among civil servants. Former Head of the State Personnel Agency (SPA) Eko Sutrisno highlighted the government's plan to early retire civil servants who entered the quadrant underperforming, not qualified, and incompetent. Because the rationalization is considered to be contradictory with one of the articles in the Law on the State Civil Apparatus that regulates the retirement age limit (RAL) which is added two years from before. According to Sutrisno, this additional retirement age limit shows that Indonesian civil servants are more productive. According to him, the early retirement policy is not the right policy especially with the issuance of the State Civil Apparatus Law, the workload of civil servants will be heavier (Pro Kalteng, March 10, 2016).

This early retirement policy was also highlighted as an ineffective policy by the Chairman of the National Council (NLC) Korpri Zudan Arif Fakrulloh. Zudan requested that the government should carefully map out the rationalization plan for the number of civil servants, so that the rationalization does not reach the desired goal, but instead creates new problems (Republika Online, January 8, 2016).
At the local level, the implementation of the State Civil Apparatus Act will be interesting considering that in practice the regional government has been run with the tendency of a more popular patronage model known as dynastic political practices such as the dynasty of Ratu Atut, the former governor of Banten Province, the practice of nepotism in North Sulawesi Province when EE Minister Mangindaan made his son Harley Mangindaan become Deputy Mayor of Manado in 2010. The same practice was carried out by the Governor of North Sulawesi SH. Sarundjang who proposed his son Ivan Sarundajang became Deputy Regent of the Minahasa. A similar case also occurred in North Sumatra Province where the election of Deli Serdang Regent, Ashari Tambunan, replaced his biological brother, Amri Tambunan who had led Deli Serdang for the previous two periods. Long ago Pelly (1994) concluded in his doctoral dissertation that ethnic intrigue and rivalry was very dominant and led to an unhealthy struggle for strategic positions in the government of North Sumatra Province.

In Law No.5 Year 2014 concerning State Civil Apparatus, the term "Fit and Proper Test" is not specifically used in the recruitment of positions in the City and Regency Governments. But in article 108, paragraph 3 , it is stated, that:

"The filling of senior pratama positions is carried out openly and competitively among civil servants by taking into account the requirements of competency, qualifications, ranks, education and training, track record of positions, and integrity and other position requirements in accordance with statutory provisions."

In the implementation, a selection committee will be involved who will take the exam and at the same time choose people who are deemed appropriate and fit to fill vacant positions. This selection 
practice is seen as a strategic mechanism to prevent unhealthy practices as mentioned above. How is the practice of the selection process and how is the perception of the apparatus and the public in seeing this matter considered important to be revealed. The practice of recruiting strategic officers in honest, clean and professional City and Regency Governments will in turn produce clean, honest and professional officials as well.

For this reason, it is deemed necessary to conduct research concerning this practice, which in the field is often referred to as a "fit and proper test" of officials. Law No. 5 of 2014 does not mention the term "Fit and Proper Test", but uses the term Competency Test.

\section{RESEARCH METHODS}

The paradigm in social science seeks to help us understand social phenomena. The paradigm presents assumptions about the reality of the world, how science should be carried out, and research problems that deserve to be researched, solutions, and criteria "proof." The paradigm includes theories, methods, initiators and followers (Firestone, Gioia, Pitre, Kuhn, 1987).

Because this study uses a qualitative paradigm, in many ways endeavors will follow the assumptions of ontology (what is the nature of reality), epistemology (what is the relationship of the researcher to the researched), axiology (what is the role of values) and methodology (what is the process of research) qualitative paradigm (Creswell 2001). In terms of methodology, the qualitative paradigm does not begin with a rigorous theoretical or thought framework and does not aim to test hypotheses, including within the framework of generalization as is appropriate in the quantitative paradigm. In other words, the design of this study is not scientifically rigid, but develops in accordance with the natural setting according to the setting and context of the study. In other words, this research is more dominant (more-less dominant) using a qualitative approach as believed by adherents to the qualitative paradigm.

The main informants in this study were the elites (executive and legislative) at Medan City and Deli Serdang and Samosir Districts. These elites can refer to regional heads, expert staff of regional heads, heads of offices, and heads of Regional Personnel Agencies (RPA), members of parliament, including nongovernmental organizations or NGOs, intellectuals, and the mass media in each area interviewed with an open interview guide.

The number of respondents in this study is not limited to a certain number and the withdrawal is not random including the determination of certain precision and sampling errors, because the aim is not to generalize (the results) of research. The number of research respondents will be stopped if the research question is considered to have been answered by the researcher himself. To maintain the accuracy of validity and reliability, data triangulation will be carried out with a check and re-check process to various informants who are considered to know the research problem being investigated.

\section{RESULTS AND DISCUSSION Strategic Position Recruitment Process in Deli Serdang Regency Government}

Law No. 5 of 2014 concerning State Civil Apparatus (SCA) changed the recruitment model of the State Civil Apparatus to fill vacant positions in government into an open recruitment model. This is similar to the recruitment model used by President Joko Widodo when he served as the Governor of the Special Capital Region known as the "office auction".

Recruitment openly appears as a mandate from Law No. 5 of 2014 concerning State Civil Apparatus (SCA). The instructions for implementing this law 
are based on the Minister of Administrative Reform and Bureaucratic Reform Regulation No. 13 of 2014.

Regional Personnel Agency (RPA) as the Implementer of the Recruitment Process, In this recruitment process the Personnel and Training Agency plays the role of organizing the selection process for High Leaders' officials. The Personnel and Training Agency made a publication regarding the opening of vacancies for the position of the High Leadership, and facilitated all needs in this process up to the stage of submitting the results of the selection to the Regent.

Selection Process Performed by the Selection Committee, carried out by the Selection Committee (Selcom) consisting of local officials and academics. Selcom is what gives value to candidates who take the recruitment process. Each Selcomm member gives an assessment to each candidate during the open recruitment stages and then the value will be accumulated so that in the end three names will be chosen with the best judgment which will be a recommendation for the Regent to choose a name to fill the position of High Leader.

Pre-requisites for Candidates for Open Recruitment, Law No. 5 of 2014 Article 19 paragraph (3) states that for each position of the High Leadership a competency, qualification, rank, education and training, track record and integrity, and other requirements are required. What is meant by other requirements needed in this case are regulated further in a Government Regulation.

Stages of the Selection Process, the process of selecting the position of the High Leadership is carried out in several consecutive stages, namely: file selection, psychological testing, paper writing and interviews. File selection is done by taking into account the requirements set out in the recruitment implementation guidelines. The second stage is psychological testing, this psychological test is held in collaboration with third parties. The third party will play a role in creating psychological test questions and evaluating the psychological results of the recruiting participants. The third stage is the writing of a paper containing the thoughts of the recruitment participants about the position they will fill. Writing the paper is done directly during the selection process before the Selcom. The interview is the final stage of the selection process by the Selcom before choosing three names that will be recommended to the Regent.

The Election of Officials who will Occupy the High Leadership Position, Three names chosen from the recruitment process carried out by the Selection Committee will be submitted to the Regent to be chosen to fill the position of the High Leadership. In this process, the Regent has full rights in considering the candidate he will elect.

Open Recruitment Budget, The new model in the recruitment process requires a budget that is not the same as what has been budgeted in the APBD. Therefore the selection process can only be done once. For the three remaining vacant positions the open recruitment process will be carried out after the adoption of the 2015 Revised Deli Serdang District Revenue Budget.

An Open Recruitment System that "Castrates" the Authority of the Regional Head? Changes in regulations in filling the position of the High Leadership were initially feared would reduce the authority of regional heads in selecting candidates with the best qualifications that could establish cooperation well. After the instructions for the implementation of open recruitment are published, it is known that the Regional Head still has the authority to determine candidates who will fill the position of the High Leadership based on recommendations given by Selcom through the selection process. 
Challenges in Open Recruitment, The open recruitment model aims to reduce the practice of nepotism in local government. According to the interviewees, this model can indeed narrow the possibility to practice nepotism because it involves a third party in the selection process. However, with the announcement of the three names that passed the selection by Selcom, it still opened the opportunity for collusion or nepotism to be carried out between the candidate and the Regent until before the Regent decided on the name chosen. The possibility for the Regent to choose his relatives or family from the three names recommended by Selcom according to sources is reasonable and acceptable since the three names recommended are candidates with the best qualifications after being selected and the Regent needs people who can communicate and establish good cooperation with him.

In conclusion, open recruitment designed to reduce the practice of nepotism also still allows the practice of nepotism. The challenge for the regional government as the organizer of the open recruitment process is the selection of third parties both to conduct the selection at the psychological test stage and as members of Selcom - are those who have a commitment to eradicate the practice of nepotism as the objective of the open recruitment process.

\section{Strategic Position Recruitment Process in Medan City Government}

Furthermore, researchers have conducted interviews at the Medan City Personnel and Training Agency and obtained the results of an interview that is not so far away with the Deli Serdang Regional Personnel and Training Agency. The Medan City Regional Personnel and Education Agency admitted that they adopted the Deli Serdang Regional Personnel and Education Agency concept as an initial model for the implementation of the fit and proper test for the first time in Medan. For more details, will be described as follows.

The fit and proper test in Medan City has been carried out for the past 3 years. In the implementation of the fit and proper test it is still carried out by Selcom. In the fit and proper test known as the existence of the highest value system and national standards, In the open selection carried out by the Medan City Personnel and Training Agency, this was determined by Selcom. Selcom is free to determine whether to use the highest value or use a passing grade system. During these 3 years, Selcom used the highest score system 2 times, while passing grade was only used 1 time. From an organizational standpoint, all open selection activities are not the full responsibility of the Regional Personnel and Training Agency, this open selection activity is held by Selcom. Even the Selcom secretariat was also formed by Selcom. Although the budget is in the Regional Personnel and Training Agency, Selcom is free to move and make decisions.

In the selection of budget openings to recruit positions is entirely the responsibility of the Regional Personnel and Training Agency, but the implementation of open selection is carried out by the Regional Secretary. The budget for open selection will come out when the Accountability Report has been completed. Regarding the openness of the announcement of the results of the open selection, the announcement was distributed online and the announcement of the paper posted on the notice board in the Medan City Personnel and Training Agency where the results of the selection results were announced openly and could be known by anyone, this was done as an antisation to minimize the perception of fraud. In the implementation of the Open Selection at the Regional Civil Service and Training Agency, Medan City experienced protests from participants who had participated in open and defeated 
selection, responding to this Regional Civil Service and Training Agency replied that it was the result of Selcom's decision. If you want to ask, please go to Selcom.

The timeframe used for the announcement of the opening of the open selection registration according to regulations is 14 days however, However, if the quota has not been met the Regional Personnel and Training Agency can request additional time from the State Civil Apparatus Commission. And the State Civil Apparatus Commission is free to give additional time. In this open selection the Regional Personnel and Training Agency has a kind of control card where the Selcom will later check, if the file requirements have been met by the applicant. File selection also uses a system score / value.

The challenges faced in the implementation of this open selection are in determining determining the date, namely, the date for interviewing candidates for the State Civil Apparatus has been set, but suddenly the interviewer who is from the Regional Personnel and Training Agency has work and must go. In coordination, the Medan City Regional Personnel and Training Agency and the Regional Personnel and Training Agency and others have a coordination meeting which is conducted once a month. In this open selection, the Medan City Personnel and Training Agency has innovated in the field of technology, namely in the interview stage, not face to face, but through online. But this innovation is no longer used today. The weaknesses of the Medan City Personnel and Training Agency are found in the assessor team. However, at present the Medan City Personnel and Training Agency has a solution namely the Computer Assisted Test procurement plan. So far the Medan City Personnel and Education Agency has sent a proposal for the procurement of Computer Assisted Test in Medan. Constraints that are often faced by the Medan City Personnel and Training Agency are on time and budget. The Regional Personnel and Training Agency believes that if the Budget is sufficient, this Open Selection can run optimally as well.

\section{Strategic Position Recruitment Process in Samosir District Government}

In Samosir Regency there are pros and cons to the enactment of the Law on the State Civil Apparatus. Some parties assume that the Law on the State Civil Apparatus has 'rammed' the regional autonomy law. This is related to the Batak culture which is still quite thick in the Samosir area. Some parties think that this law has made civil servants more difficult. Especially in Batak culture with the clan system. How could the Manihuruk clan become regents in North Tapanuli. The regent in Taput must have a large clan that lives and opens a village there, or a pamungka huta clan (the clan who first opened the village), such as Hutabarat, Panggabean, Lumban Tobing and other large clans. The clan is the pride of the Batak people, so indeed at a certain level the appointment of strategic officials is sometimes affiliated with the clan. But it has not yet reached dynastic politics. Maybe the Manihuruk clan could also be a regent in North Tapanuli, if he had a lot of money by conducting money politics during the elections.

An informant from the Regional House of Representatives in Samosir Regency has the same opinion. He said there was a tendency for fit and proper tests to be made an 'alibi' by the regional head. Even so, this system is considered to be more advanced. Because in the past, regional heads could act as they pleased and appoint strategic officials based only on whether they liked it or not. This regulation is one step ahead, more important to supervise (as part of the legislative function) is whether the 
mechanism of recruitment of the committee is transparent. The process of propriety testing has been carried out with stages (administration, psychological testing, interviews, etc.) in a transparent and accountable manner. This process is more necessary. This fit test is good because it can be a platform for recruiting strategic positions throughout Indonesia, so there is macro guidance. Not carelessly as long as there is. If there is a shortage, academics or anyone can submit a judicial review to the Constitutional Court (CC). Moreover, even without this propriety test, there has always been a tendency for recruitment and transfer of strategic positions to be used by regional heads to receive commissions. So, you must think positively, don't see everything from the negative side. If there are weak gaps and shortcomings, it's better to have a judicial review.

As a general description of the propriety and feasibility testing process carried out by the Samosir Regional Personnel and Training Agency that is adjusting to Law No. 5 of 2014 fit and proper test with Selection, and based on PP No 11 of 2017 selected are leaders of high positions, pratama namely Echelon II, from the blooming point of view who has the authority is Mr. Regent as the Official Officer of Regional Personnel, then formed Selcom whose elements the element consists of the Regional Secretary (in ex oficio) being the Chair of the Selection, other elements are internal, namely the District Government official as long as there is no opportunity for intervening conflict space, for example now the Regional Personnel and Training Agency is conducting a selection, the Regional Secretary serves as Chair, Head Bappeda as Committee secretary, Chair of the secretariat team is the Head of the Regional Personnel and Training Agency and its elements in the secretariat. The team was given permission by the Regent, and of course the Regents regarding the selection requirements. Then the procurement or selection planning document for this selection is sent to the State Civil Apparatus Commission. The names of the attached Selcom team were also sent to the State Civil Apparatus Commission.

In the process of announcing open selection conducted by the Regional Personnel and Training Agency through Print Media and Online Media. Where, this was done by the Committee Secretary. What is meant by open here is to have a scope or region, which is a district scope with various considerations, the provincial Skop and the National scope. But in its implementation applicants from outside the city of Samosir were very minimal. The Secretary believes that this is due to many considerations from the applicant. Like family, welfare and others. And applicants in this open selection are only those who are engaged in civil servants but the private sector is not given space.

In the formation of Selcom based on Regulation Requirement No. 11 of 2017 concerning Management of State Civil Apparatus mandating the formation of Selcom with elements that must be included in the committee, the Government Employees with a Work Agreement namely the Regional Head form or allow Selcom. Regional Secretary because ex ofio became chairman. From the District Government elements appointed by the Regent as well as from outside. Those from outside who sat in Selcom were also from Universities.

Selcom's notification mechanism is through the mail media. Those who sit on the or Selection Committee are adjusted to the needs of the Dinas. For example, vacant positions exist in Agriculture so it is expected that people have the competence / ability in that field which is Selcom. And the letter was sent to the institution not to the individual. Samosir strives to empower local universities or the current region which, as currently the Samosir Regional 
Personnel and Training Agency, involves UNITA Higher Education.

Differences in the results of open selection compared to before the existence of this selection certainly there are differences, namely, the law mandates that there be an assessment test from an assessment agency that has certification, Samosir himself uses an assessment from the Regional Police, but there are also assessment institutions from the State Personnel Agency. Samosir used the assessment from the Polda because Samosir saw that the development of human resources in the Polda was already good and certified. And to the knowledge of the North Sumatra Regional Police Samosir together with the National Police. Through this Assessment, the Samosir Regional Personnel and Training Agency will get information in the field of psychological testing and the tendencies of the participants they are netting.

The test in this selection consists of Assessment, competency test that is making papers, then Selcom testing. Previously Selcom in Samosir came from Unika, from Nomensen there was also, for more complete documents available at the Secretariat of the Regional Personnel and Training Agency. Selcom consists of the Regional Secretary as the Chair of Selcom in ex oficio, from the Regency Government, from outside, for example from lecturers and from the community, taking into account their competencies, such as experience in bureaucrats such as retirees. Selcom number is odd 3,5,7. Furthermore, the interview selection is based on a paper made by the applicant. Where is the interview about the paper.

In guaranteeing that this process has been carried out objectively, the Secretary of the Samosir District analogy can not guarantee it fully because only God can guarantee, but with the mandate of this Law, Samosir strives to be more objective than before. As we know, the Regent was the King.

If in Deli Serdang a Computer Assisted Test application is known, but in Samosir it has not used the application. This is because of the circumstances, it is not possible to make a passing grade while the number of applicants / applicants in this selection, especially from outside is small. It is feared that if there is no passing grade system that meets the requirements, the position will be vacant. If responsibility is empty and results in performance in the field is not running.

This open selection has already taken place with an open scope for North Sumatra, and also once in the district scope even in the selection of Regional Secretary has experienced this process. but applicants / applicants from none. Strong suspicion this is due to many considerations from the applicant. The Samosir government has a stipulation that an appointed official must be prepared to stay with his family in Samosir. Of course the Regent has a consideration on this matter. As we know, the task of the regency / city government is development and social society. This social task is very thick in Samosir. Sundays are also busy with social community such as church events, mosques. Therefore the official must sign the Integrity Pact, which contains the matter.

This selection has been held 4 times. And the obstacles experienced in this Open Selection do not exist, but if asked whether the optimal officials produced are professional and competent? There we cannot guarantee. But if in the selection process, there are almost no obstacles, the vacancies offered by the participants, the selection results are found by the person. our hopes to be more optimal. The number of applicants in one vacancy is based on the approval of a minimum of 4 people. If the Regional Personnel and Training 
Agency has not been met, it can extend the registration schedule.

By looking at the small number of applicants, it is feared that there will already be construction in the field if those who will be elected to occupy the positions have been arranged, but when asked about this, the Secretary only gives an analogy that only God's eyes can see $100 \%$. It means something is hidden. Maybe it is psychologically the community, but I as the organizer does not exist. This is because no one registered.

\section{CONCLUSION}

'Research findings indicate that the Implementation of the Fit and Proper Test of Strategic Officers has been carried out in Medan City Government, Deli Serdang Regency Government and Samosir Regency Government with different results. The implementation of the Decency Test and Feasibility of Strategic Officers that have been carried out in the Medan City Government apparently has produced results that are in line with expectations, with the election of competent officials in the positions they occupy. The implementation of the Decency Test and Feasibility of Strategic Officers has been carried out in the Deli Serdang Regency Government, but it also provides results that are as expected, namely a selection process that results in competent officials. The implementation of the Decency and Feasibility Test conducted at the Samosir Regency Government still experiences pros and cons. This is related to Batak culture which is very thick in the area. The law on state civil apparatus (SCA) has not been fully implemented by the City and district governments in North Sumatera.

\section{BIBLIOGRAPHY}

Pelly, U. (1984). Urbanisasi dan Adaptasi Misi Budaya Merantau: Peranan Misi Budaya Minangkabau dan Mandailing. Jakarta: LP3S

Marshal, C. dan Rossman, G.B. (1989). Designing Qualitative Research. London: Sage Publication, Ltd.

Botero, J.C. dan Ponce, A. (2015). The WJP Open Government Index 2015. Washington DC, World Justice Project
Toha, M. (2003). Ilmu Administrasi Negara. Jakarta: Grasindo Persada

Wahab, S.A. (2005). Analisis Kebijakan dari Formulasi ke Implementasi Kebijaksanaan Negara. Jakarta: Bumi Aksara

Parson, W. (1997). Public Policy, An Intoduction to the Theory and Prctice of Policy Analysis. U.K: Aldershot Edward Elgar Publishing

Edward III, George C. (1980). Implementing Public Policy. Washington DC: Congressional Quarterly Press

Sobur, A. (2003). Psikologi Umum. Bandung: Pustaka Setia.

Stenberg, J.R. (2008). Psikologi Kognitif. Yogyakarta: Pustaka Pelajar.

Shaleh, A.R. (2009). Psikologi Suatu Pengantar Dalam Perspektif Islam. Jakarta: Kencana.

Rakhmat, J. (1996). Keluarga Sakinah, Suatu Tinjaun Psikologi dan Agama. Yogyakarta: Pustaka Belajar.

Sarwono, S. (2009). Pengantar Psikologi Umum. Jakarta: Rajawali Press

Walgito, B. (2003). Psikologi Sosial. Yogyakarta: C.V Andi Offset.

Thoha, M. (2007). Perilaku Organisasi, Konsep Dasar dan Aplikasinya. Jakarta: P.T. Rajagrafindo Perkasa.

Dimyati dan Mudjiono. (2006). Belajar dan Pembelajaran. Jakarta: Rineka Cipta.

Slameto. (2010). Belajar dan Faktor-faktor yang Mempengaruhinya. Jakarta: Rineka Cipta.

Nurprojo, I.S. (2014). "Merit System dan Politik Birokrasi di Era Otonomi Daerah" dalam Jurnal Kebijakan dan Man.

Dwiyanto, A. (2006). Mewujudkan Good Governance melalui Pelayanan Publik. Yogyakarta: Gadjah Mada University Press

Nugroho, R. (2014). Public Policy. Jakarta: PT. Elex Media Komputindo

Prasodjo, E, (2014), Undang-Undang Aparatur Sipil Negara: Membangun Profesionalisme Aparatur Sipil Negara, Jurnal Kebijakan dan Manajemen PNS, Vol 8 No 1 Juni: 13-29.

Firestone, W.A. (1987). Meaning in Method: The Rhetoric of Quantitative and Qualitative Research. Education Researcher, 16 (7): 1621.

Gioia, D.A. dan Pitre, E. (1990). Multiparadigm Perspectiveson Theory Building. Academy of Management Review, 15 (4), 584-602.

Kuhn, T. (1970). The Structure of Scientific Revolutions. University of Chicago Press. Chicago.

Creswell, J.W. (1994). Research Design Qualitatif \& Quantitatif Approaches. Sage Publications, Inc. California.

Kumorotomo, W. (2013). Lelang Jabatan. Diakses pada 9 Oktober melalui 
http://kumoro.staff.ugm.ac.id/file_artikel/Le lang\%20Jabatan.pdf.

Nurwana, M. A. Evaluasi Lelang Jabatan di Lingkungan Pemprov Jawa Tengah tahun 2013-2014. UNDIP. Diakses pada 9 Oktober 2018

melalui https://media.neliti.com/media/publication
s/104718-ID-evaluasi-lelang-jabatan-dilingkungan-pe.pdf.

https://samosirkab.go.id/web/aparaturpemerintahan/, diakses pada 9 Oktober 2018.

UU No. 5 tahun 2014 tentang Aparatur Sipil Negara. 